dr inż. Marek Sobaś

Instytut Pojazdów Szynowych ,TABOR”

\title{
Nowoczesne rozwiązania konstrukcyjne pojazdów tramwajowych z uwzględnieniem wymagań skrajni kinematycznej
}

\begin{abstract}
Artykut jest poświęcony nowoczesnym rozwiqzaniom konstrukcyjnym pojazdów tramwajowych z uwzględnieniem wymagań skrajni kinematycznej. Przedstawiono tendencje rozwojowe pojazdów szynowych $i$ ich podzespołów oraz elementów $w$ ostatnich latach. Uzasadniono konieczność realizacji poszukiwania optymalnego zarysu pojazdu w powiqzaniu z innymi wymaganiami jak np. ulżenie konstrukcji, budowa modułowa pojazdu itp.

Artykut powstat w ramach projektu badawczego $\mathrm{nr} N 509$ 03531/2367, finansowanego

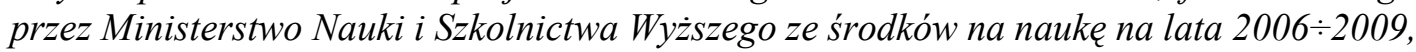
pt.: „Metodyka wyznaczania kinematycznego zapotrzebowania przestrzeni oraz luzów bezpieczeństwa dla pojazdów tramwajowych, celem ustalenia optymalnego zarysu pojazdu”.
\end{abstract}

\section{Wstęp}

Jak wykazano w pracach $[8 \div 13]$ istotnym czynnikiem wpływającym na ostateczny kształt pojazdów tramwajowych jest zarys odniesienia skrajni kinematycznej oraz skrajni budowli. Istotą procesu projektowania pojazdu tramwajowego jest znalezienie jego optymalnego kształtu, spełniającego zasadnicze wymagania klienta, wynikające $\mathrm{z}$ gospodarki rynkowej oraz obowiązujących przepisów. W związku z powyższym na każdego z producentów poszczególnych podzespołów dla taboru tramwajowego jest wywierany nacisk, aby wykonywać elementy o bardzo zwartej budowie (niem.,,kompakte Bauweise”), zajmującej możliwie najmniejszą przestrzeń, przy jednoczesnym zmniejszeniu masy własnej oraz przy zachowaniu własności funkcjonalnych, wysokiego poziomu niezawodności i wytrzymałości. Logicznym następstwem przy konstrukcjach tramwajów $\mathrm{z}$ obniżoną podłogą jest kompaktowa budowa układy biegowego oraz usytuowanie wielu podzespołów na dachu pojazdu tramwajowego. Kolejnym wyzwaniem rynkowym jest zwiększenie wskaźnika przepustowości ( mobilności) dla podróżnych podczas wsiadania i wysiadania. Przykładem takiego rozwiązania może być nowoczesny siedmioczłonowy tramwaj przegubowy $\mathrm{z}$ obniżoną podłoga typu „Combino Classic” opracowany przez Siemiens Trasnportation Systems i przeznaczony dla miejskiego przedsiębiorstwa komunikacyjnego Berner Verkehrsbetriebe Bernmobil (Szwajcaria) o długości $42 \mathrm{~m}$, który jest dłuższy od dotychczasowej wersji o $11 \mathrm{~m}$ ( Combino Advanced von Bern ), co z kolei zwiększa wskaźnik przepustowości podróżnych o $30 \%$ [17]. Trudno nie zgodzić się z poglądem zaprezentowanym w [1], że klienta w ogólne nie interesuje jak jest zbudowany pojazd, natomiast jest zainteresowany jego funkcjonalnością i dobrą ceną.

\section{Nowoczesne rozwiązania układów biegowych} 2.1. Przykłady rozwiązań układów napędowych

Jak zasygnalizowano w [4] układy biegowe dla tramwajów niskopodłogowych muszą posiadać

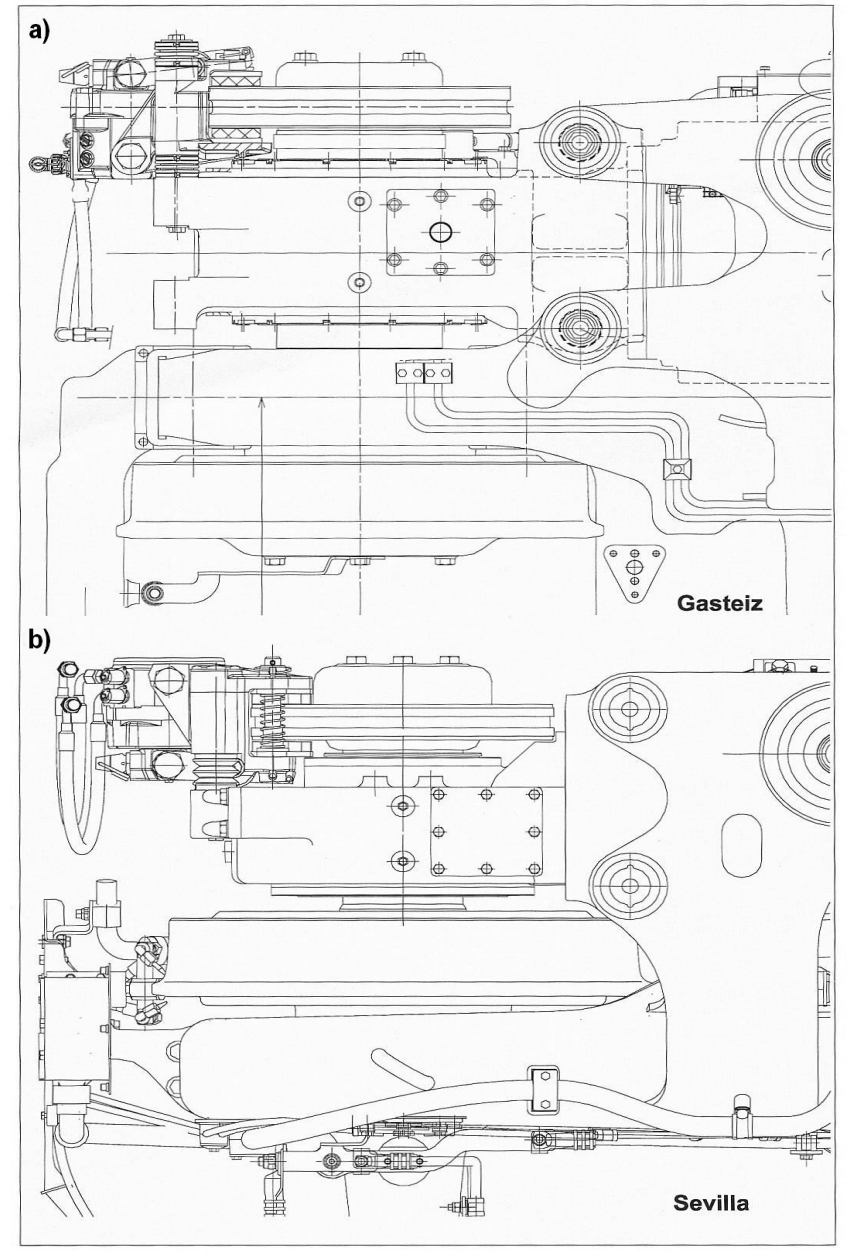

Rys.1. Trakcyjne układy biegowe dla Gesteiz dla toru o prześwicie $1000 \mathrm{~mm}$ (rys1a) i Sevilli dla toru o prześwicie 1435 mm (rys.1b) wg [4]

zwarta, kompaktową budowę, z uwagi na niewielką przestrzeń do dyspozycji. Jest to wynikiem coraz większego nacisku na obniżenie wysokości podłogi w stosunku do poziomu główki szyny. Przykład rozwoju konstrukcji zwartych wózków trakcyjnych wynika $\mathrm{z}$ porównania ich układów napędowych. Na rys.1 przedstawiono dwa trakcyjne układy biegowe dla Vitoria 
Gesteiz z przekładnią $\mathrm{z}$ boku koła dla toru o prześwicie $1000 \mathrm{~mm}$ ( u góry rys.1) oraz dla Sevilli z przekładnią z boku koła dla toru o prześwicie 1435 mm ( u dołu rys.1). Usytuowanie silnika trakcyjnego jest takie same w obydwu wózkach. Obydwa układy biegowe zostały opracowane dla tramwajów wykonanych przez firmę CAF.

$\mathrm{Na}$ rys.2. przedstawiono nowoczesne rozwiązanie trakcyjnego układu biegowego bezprzekładniowego ( niem. ,getriebelose Antrieb”), zastosowane w pojazdach tramwajowych firmy Stadler [4].

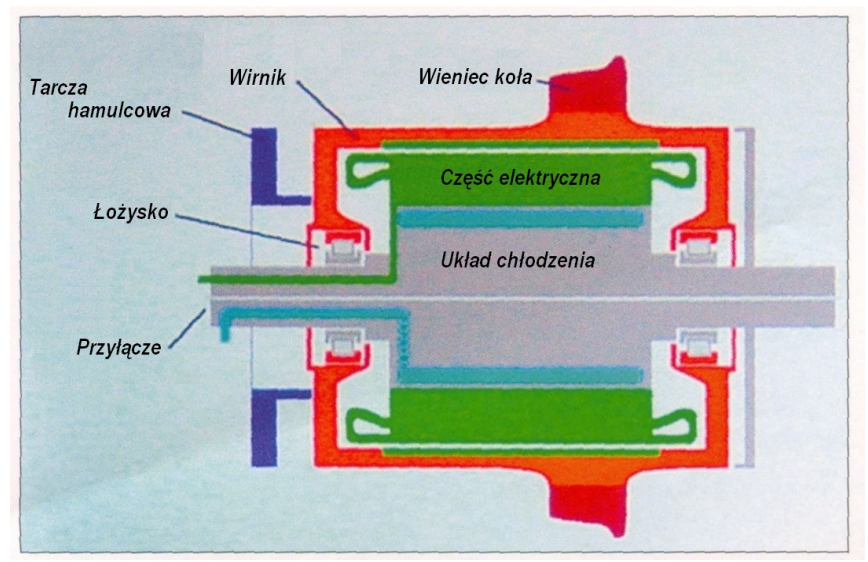

Rys.2. Rozwiązanie bezprzekładniowe $\mathrm{z}$ bezpośrednim ośmiobiegunowym silnikiem asynchronicznym ( niem. ,achtpolige Direkt-Asynchronmotor") firmy Stadler [4]

Zaletą rozwiązania bezprzekładniowego sytemu napędowego jest:

$>$ usunięcie źródła hałasu, jakim jest przekładnia mechaniczna

$>$ brak strat energii w przekładni

$>$ mniejszy poziom emisji hałasu przez silnik trakcyjny w dolnym i górnym zakresie prędkości

$>$ mniejszy poziom hałasu emitowany przez system chłodzenia

$>$ brak prac konserwacyjnych związanych $\mathrm{z}$ przekładnią

$>$ brak zapotrzebowania na smarowanie olejem przekładni

$>$ mniejsza masa napędu

$>$ mniejsza masa nieusprężynowana,

natomiast wadą jest to, że bezpośredni ośmiobiegunowy silnik asynchroniczny wykazuje współczynnik sprawności w punkcie obciążenia, który jest mniejszy o około $20 \%$ niż przy kombinacji silnik trakcyjnyprzekładnia. Układ bezprzekładniowy jest rozwiązaniem przyszłościowym, tym bardziej że jest on stosowany również $\mathrm{w}$ zespołach trakcyjnych przystosowanych do wysokich prędkości [4].

\subsection{Konstrukcje silników trakcyjnych}

Do napędu pojazdów tramwajowych stosuje się obecnie silniki asynchroniczne $\mathrm{z}$ dwoma systemami chłodzenia:

- chłodzenie powietrzem

- chłodzenie substancjami ciekłymi ( woda, glikol, olej przekładniowy) [6].

W przypadku silników asynchronicznych chłodzonych powietrzem (niem.,, Traktionsmotoren mit Luftkühlung") średnia prędkość strumienia powinna wynosić 20 do $30 \mathrm{~m} / \mathrm{s}$. Przy takich prędkościach powietrza w systemie jego przepływu występuje bardzo duża emisja hałasu, pojawiająca się przede wszystkim przy zmianie kierunku oraz ostrych przejściach $\mathrm{w}$ przewodach przelotowych. Kolejnym parametrem wpływającym na efektywność systemu chłodzenia jest spadek ciśnienia pomiędzy wlotem i wylotem powietrza na korpusie silnika. Miarodajnymi czynnikami dla całkowitego spadku ciśnienia powietrza chłodzącego są wymuszone zmiany kierunku, zmniejszenia i zwiększenia przekroju poprzecznego. Spadek ciśnienia w pakiecie blach żelaznych wirnika i stojana wynosi jedynie ok. 10 do 20\% całkowitego spadku. Zaleta zastosowania silników chłodzonych strumieniem powietrza jest bardzo dużą ilość ciepła oddawana przez powierzchnię pakietu blach żelaznych wirnika i stojana, która może być jeszcze powiększona przez poosiowe otwory wentylacyjne.

Moc strat cieplnych oddawana przez strumień ciekłego środka chłodzącego jest wyrażona wzorem:

$$
\mathrm{P}_{\text {strat }}=\mathrm{m}^{\prime} \cdot \mathrm{c}_{\text {Pow }} \cdot \Delta \mathrm{T}_{\text {pow }}
$$

gdzie:

m' - masa środka chłodzącego [kg]

$\mathrm{c}_{\text {pow }}$ jednostkowa pojemność cieplna powietrza [Ws/kg.K]

$\Delta \mathrm{T}_{\text {pow }}$ - podgrzanie powietrza chłodzącego [? $\left.\mathrm{K}\right]$ a po wstawieniu $\mathrm{m}^{\prime}=\mathrm{V}_{\text {pow }} \cdot \rho_{\text {pow }}$ otrzymuje się:

$$
\mathrm{P}_{\text {strat }}=\mathrm{V}_{\text {pow }}{ }^{\prime} \cdot \rho_{\text {pow }} \cdot \mathrm{c}_{\text {pow }} \cdot \Delta \mathrm{T}_{\text {pow }}
$$

gdzie:

$\mathrm{V}_{\text {pow }}$-gęstość strumienia powietrza $\left[\mathrm{m}^{3} / \mathrm{s}\right]$ $\rho_{\text {pow- }}$ gęstość środka chłodzącego $\left[\mathrm{kg} / \mathrm{m}^{3}\right]$.

Silniki asynchroniczne chłodzone za pomocą substancji ciekłych (niem.,, Traktionsmotoren mit Flüssigkeitskühlung") mają istotną zaletę polegającą na tym, że są one całkowicie zamknięte i wskutek tego zabezpieczone przez wnikaniem zanieczyszczeń, kurzu i wilgoci. Korpus stojana jest wykonany w postaci podwójnego płaszcza ( niem.,, Doppelmantel”), który 
napełniony substancją ciekłą tłumi emisję hałasu. Oddawanie ciepła przez stojan odbywa się bezpośrednio przez środek chłodzący, natomiast przez wirnik pośrednio przez szczeliny powietrzne i łożyska, co powoduje, że chłodzenie przez podwójny płaszcz odbywa się zasadniczo przez pakiet blach stalowych. Moc strat cieplnych przez strumień ciekłego środka chłodzącego jest zgodna ze wzorem:

gdzie:

$$
\mathrm{P}_{\text {strat }}=\mathrm{m}^{\prime} \cdot \mathrm{c}_{\mathrm{Kf}} \cdot \Delta \mathrm{T}
$$

m'- masa środka chłodzącego [kg]

$\mathrm{c}_{\mathrm{Kf}}$-jednostkowy pojemność cieplna [Ws/kg.K]

$\Delta \mathrm{T}$ - podgrzanie substancji ciekłej [? $\mathrm{K}]$

a po wstawieniu $\mathrm{m}^{\prime}=\mathrm{V}^{\prime} \cdot \rho_{\mathrm{Kf}}$ otrzymuje się:

gdzie:

$$
\mathrm{P}_{\text {strat }}=\mathrm{V}^{\prime} \cdot \rho_{\mathrm{Kf}} \cdot \mathrm{c}_{\mathrm{Kf}} \cdot \Delta \mathrm{T}
$$

V'- gęstość strumienia środka chłodzącego $\left[\mathrm{m}^{3} / \mathrm{s}\right]$

$\rho_{\mathrm{Kf}}$ gęstość środka chłodzącego $\left[\mathrm{kg} / \mathrm{m}^{3}\right]$.

Aby zwiększyć warunki temperaturowe silników trakcyjnych chłodzonych za pomocą substancji ciekłych, a przede wszystkim zwiększyć możliwość oddawania ciepła przez wirnik zaproponowano następujące przedsięwzięcia konstrukcyjne: zastosowanie wewnętrznego wentylatora ( niem. „Innenventilator”) i otworów wentylacyjnych (niem. „Kühlbohrungen) usytuowanych w kierunku równoległym do osi w stojanie i wirniku w celu polepszenia odprowadzenia ciepła w pakiecie blach stalowych

$>$ chłodzenie wału wirnika za pomoca ciekłego medium przy zastosowaniu uszczelnień za pomocą pierścieni ślizgowych

$>$ zastosowanie korpusów silników wykonanych $\mathrm{z}$ aluminium

$>$ jednostronne lub dwustronne chłodzenie pokryw łożysk wirnika.

Porównanie parametrów cieplnych asynchronicznych silników chłodzonych powietrzem oraz substancjami ciekłymi jest przedstawione w tabeli $1 \mathrm{wg}$ [6].

Zalety silników chłodzonych substancjami ciekłymi:

$>$ małe emisja hałasu pomimo wysokiej prędkości obrotowej silników z małą objętością zabudowy

$>$ wnętrze silnika zabezpieczone przed zanieczyszczeniami

> małe przekroje przyłączeniowe dla płynu chłodzącego

> bardzo duża możliwość termicznego przeciążenia w ciągu dłuższych okresów czasu

$>$ możliwość chłodzenia silnika również w stanie postoju.

Zestawienie parametrów strumienia cieplnego dla trakcyjnych silników asynchronicznych chłodzonych powietrzem oraz substancjami ciekłymi

\begin{tabular}{|c|c|c|c|c|c|}
\hline L.p. & Nazwa parametru & Oznaczenie & Jednostka & $\begin{array}{l}\text { Silnik chłodzony } \\
\text { powietrzem }\end{array}$ & $\begin{array}{c}\text { Silnik chłodzony } \\
\text { substancjami cie- } \\
\text { kłymi }\end{array}$ \\
\hline 1. & $\begin{array}{l}\text { Średnia temperatura } \\
\text { środka chłodzącego }\end{array}$ & & ${ }^{\circ} \mathrm{C}$ & 60 & 70 \\
\hline 2. & $\begin{array}{c}\text { Zdolność do przewo- } \\
\text { dzenia ciepła }\end{array}$ & $\lambda$ & $\mathrm{W} / \mathrm{mK}$ & 0,029 & 0,044 \\
\hline 3. & $\begin{array}{l}\text { Współczynnik przej- } \\
\text { mowania ciepła }\end{array}$ & $\alpha$ & $\mathrm{W} / \mathrm{m}^{2} \mathrm{~K}$ & 56 & 1900 \\
\hline 4. & $\begin{array}{c}\text { Jednostkowa pojemność } \\
\text { cieplna }\end{array}$ & c & Ws/kgK & 1,009 & 3600 \\
\hline 5. & $\begin{array}{c}\text { Gęstość ( masa właści- } \\
\text { wa)) }\end{array}$ & $\rho$ & $\mathrm{kg} / \mathrm{m}^{3}$ & 1,0452 & 1048 \\
\hline 6. & $\begin{array}{c}\text { Jednostkowa objęto- } \\
\text { ściowa pojemność } \\
\text { cieplna }\end{array}$ & $c \cdot \rho$ & $\mathrm{Ws} / \mathrm{m}^{3} \mathrm{~kg}$ & 1,0546 & 3772800 \\
\hline \multicolumn{6}{|c|}{ Przykład porównawczy dla silnika trakcyjnego $P_{a b}=200 \mathrm{~kW}(\eta=93,5 \%)$} \\
\hline 7. & Moc strat cieplnych & $\mathrm{P}_{\mathrm{verl}}$ & $\mathrm{W}$ & 14000 & 14000 \\
\hline 8. & $\begin{array}{l}\text { Różnica temperatur } \\
\text { Wejście-wyjście }\end{array}$ & $\Delta \mathrm{T}$ & $\mathrm{K}$ & 30 & 8 \\
\hline \multirow[t]{2}{*}{9.} & \multirow{2}{*}{$\begin{array}{l}\text { Strumień czynnika } \\
\text { chłodzącego }\end{array}$} & \multirow[t]{2}{*}{$\overrightarrow{V^{\prime}}$} & $\mathrm{m}^{3} / 1$ & 0,48 & 0,00046 \\
\hline & & & $1 / \mathrm{min}$ & 26500 & 27,8 \\
\hline 10. & $\begin{array}{c}\text { Przekrój poprzeczny } \\
\text { strumienia }\end{array}$ & $\bar{A}$ & $\mathrm{~mm}^{2}$ & 22000 & 1500 \\
\hline 11. & Prędkość strumienia & W & $\mathrm{m} / \mathrm{s}$ & 20 & 0,31 \\
\hline
\end{tabular}

Tabela1 
Dane asynchronicznych silników trakcyjnych chłodzonych substancjami ciekłymi, zastosowanych w taborze tramwajowym typu 4WXA25 wg [6]

Tabela 2

\begin{tabular}{|c|c|c|c|c|c|}
\hline \multirow[b]{2}{*}{ L.p. } & \multirow[b]{2}{*}{ Opis parametru } & \multirow[b]{2}{*}{ Jednostka } & \multicolumn{3}{|c|}{ Oznaczenie seryjne silnika } \\
\hline & & & 2528 & 2544 & 2557 \\
\hline 1. & Moc & $\mathrm{kW}$ & 60 & 95 & 127 \\
\hline 2. & Prędkość obrotowa & obr/min & 2006 & 2004 & 2008 \\
\hline 3. & Moment obrotowy & $\mathrm{Nm}$ & 309 & 453 & 604 \\
\hline 4. & Napięcie & $\mathrm{V}$ & 355 & 363 & 410 \\
\hline 5. & Natężenie prądu & $\mathrm{A}$ & 145 & 200 & 235 \\
\hline 6. & Masa & $\mathrm{kg}$ & 225 & 275 & 330 \\
\hline 7. & Klasa izolacji & & 200 & 200 & 200 \\
\hline
\end{tabular}

Zalety dla pojazdów trakcyjnych z zamontowanymi silnikami chłodzonymi substancjami ciekłymi:

$>$ brak kanałów powietrznych i mieszków w systemie doprowadzenia powietrza

$>$ brak filtrów powietrza

$>$ dowolne rozmieszczenie urządzenia schładzającego rozgrzane chłodziwo

$>$ mały poziom emisji hałasu urządzenia schładzającego chłodziwo

$>$ możliwość tworzenia wspólnego układu chłodzenia dla silników trakcyjnych, falowników i oporników

$>$ możliwość wykorzystania strat cieplnych do ogrzewania wnętrza pojazdu.

Wady silników chłodzonych substancjami ciekłymi:

$>$ małe chłodzenie wirnika (przy zastosowaniu tylko chłodzenia dwupowłokowego lub dwupłaszczowego (niem.,,Doppelmantelkühlung”)

$>$ nieznaczne oddziaływanie środków chłodzących na łożyska silnika przy zastosowaniu chłodzenia dwupłaszczowego

$>$ ograniczona moc silników ( maksymalnie do $250 \mathrm{~kW}$ )

$>$ przy równych wymiarach zewnętrznych konieczność zmniejszenia aktywnej średnicy stojana $z$ uwagi na kanał chłodniczy

Wady dla pojazdów trakcyjnych z zamontowanymi silnikami chłodzonymi substancjami ciekłymi:

> konieczność instalacji urządzenia do chłodzenia rozgrzanej substancji chłodzącej

$>$ kosztowne prace konserwacyjne $\mathrm{z}$ uwagi na zastosowanie urządzenia chłodzącego.
Przykłady asynchronicznych silników trakcyjnych chłodzonych substancjami ciekłymi są podane w tabeli 2 .

Ww. silniki trakcyjne zostały zastosowane w tramwajach niskopodłogowych dla Antwerpii, Bielefeld, Darmstadt, De Lijn ( Holandia), Erfurtu, Essen, Freiburga, Heidelbergu, Karlsruhe, Lipska, Ludwigshafen, Magdeburga, Mannheim, Rostocku i Zurychu. W przypadku silników z chłodzeniem dwupowłokowym wirnik średnio chłodzony przez szczelinę powietrzną względnie przez łożyska. Dlatego wykorzystanie mocy nie jest ograniczone tylko w części elektrycznej przez wysokie temperatury ( uzwojenie wirnika i stojana), lecz również w cześci mechanicznej przez maksymalne temperatury łożysk. Dla łożysk kulkowych zwykłych i łożysk walcowych maksymalna temperatura graniczna wynosi $130 \div 150^{\circ} \mathrm{C}$. Należy to uwzględnić przy termicznym projektowaniu wirnika. Dodatkowo przy wysokim poziomie temperatur smar w łożyskach jest również elementem obciążonym termicznie. Smary na bazie olejów mineralnych pozwalają na największą temperaturę eksploatacyjną $130 \div 140^{\circ} \mathrm{C}$, natomiast na bazie syntetycznej $150 \div 160^{\circ}$ C. Niezależnie od gatunku smaru, zwiększenie temperatury łożyska o $10^{\circ} \mathrm{C}$, zmniejsza okres użytkowania smaru o połowę. Kolejnym istotnym ograniczeniem są części wirnika, które nie mogą być uszkodzone wskutek oddziaływania temperatury. Wykaz cześci wirnika wraz z dopuszczalną temperatura jest przedstawiony w tabeli 3 .

Wykaz części wirnika wraz z ograniczeniami temperaturowymi wg [6]

Tabela 3

\begin{tabular}{|c|c|c|c|c|}
\hline L.p. & Część konstrukcyjna & Materiał & $\begin{array}{c}\text { Skutki obciążenia } \\
\text { temperaturowego }\end{array}$ & $\begin{array}{c}\text { Temperatura } \\
\text { graniczna }\end{array}$ \\
\hline 1. & Blacha wirnika & $\begin{array}{c}\text { Blacha prądnicowa } \\
\text { z izolacją lakierową }\end{array}$ & $\begin{array}{c}\text { Uszkodzenia lakieru zwięk- } \\
\text { szają straty żelaza }\end{array}$ & ok.250 ${ }^{\circ} \mathrm{C}$ \\
\hline 2. & Uzwojenie zwarciowe & Miedź & $\begin{array}{c}\text { Zmniejszenie wytrzymałości } \\
\text { mechanicznej i zwiększenie } \\
\text { rezystancji }\end{array}$ & $\mathrm{ok} .300^{\circ} \mathrm{C}$ \\
\hline 3. & $\begin{array}{c}\text { Pierścień skurczowy dla mecha- } \\
\text { nicznego zabezpieczenia pierście- } \\
\text { ni krótkozwartych przed skutkami } \\
\text { obciążenia silą odśrodkową }\end{array}$ & Stop brązu & $\begin{array}{c}\text { Zmniejszenie wytrzymałości } \\
\text { mechanicznej }\end{array}$ & $\mathrm{ok} \cdot 300^{\circ} \mathrm{C}$ \\
\hline 4. & Wirnik & $\begin{array}{c}\text { Stal chromowo- } \\
\text { niklowa }\end{array}$ & $\begin{array}{c}\text { Zmniejszenie wytrzymałości } \\
\text { mechanicznej i wydłużenia }\end{array}$ & $\mathrm{ok} .200^{\circ} \mathrm{C}$ \\
\hline
\end{tabular}


Dane asynchronicznych silników trakcyjnych chłodzonych substancjami ciekłymi, zastosowanych w taborze metra i szybkiej kolei miejskiej typu 4WXA35 wg [6]

Tabela 4

\begin{tabular}{|c|c|c|c|c|c|}
\hline \multirow[b]{2}{*}{ L.p. } & \multirow[b]{2}{*}{ Opis parametru } & \multirow[b]{2}{*}{ Jednostka } & \multicolumn{3}{|c|}{ Oznaczenie seryjne silnika } \\
\hline & & & 3553 & 3549 & 3558 \\
\hline 1. & Moc & $\mathrm{kW}$ & 125 & 135 & 200 \\
\hline 2. & Prędkość obrotowa & obr/min & 1820 & 2001 & 2303 \\
\hline 3. & Moment obrotowy & $\mathrm{Nm}$ & 656 & 644 & 829 \\
\hline 4. & Napięcie & $\mathrm{V}$ & 470 & 570 & 1325 \\
\hline 5. & Natężenie prądu & $\mathrm{A}$ & 206 & 178 & 114 \\
\hline 6. & Masa & $\mathrm{kg}$ & 504 & 460 & 550 \\
\hline 7. & Klasa izolacji & & $\mathrm{F}$ & 200 & 200 \\
\hline
\end{tabular}

Bardzo dobra przydatność asynchronicznych silników trakcyjnych zachęciła do stosowania producentów zespołów trakcyjnych szybkich kolei miejskich (Hamburher Hochbahn) i metra (Wiener U-Bahn), pojazdów podmiejskich należących do Deutsche Bahn AG. Parametry tych silników są przedstawione w tabeli 4 .

Obecnie jest zastosowanych 5000 asynchronicznych silników trakcyjnych chłodzonych ciekłymi substancjami w tramwajach, pojazdach trakcyjnych metra $\mathrm{i}$ szybkiej kolei miejskiej ( o mocy w zakresie $65 \div 200$ $\mathrm{kW}$ ). Głównym producentem silników tego typu jest firma DaimlerChrysler Rail Systems, której poprzedniczki BBC, ABB, ABB-Daimler rozpoczęli produkcję już 20 lat temu. Pierwszy prototypowy silnik posiadał moc $120 \mathrm{~kW}$ oraz prędkość obrotową wynoszącą ok. 2000 obrotów na minutę. Silnik prototypowy był wyposażony w 30 czujników temperatury w celu umożliwienia obserwacji własności termicznych.

\subsection{Konstrukcje chłodnic dla silników trakcyjnych}

Zalety asynchronicznych silników trakcyjnych chłodzonych za pomocą substancji ciekłych i ich coraz częstsze zastosowanie $\mathrm{w}$ taborze tramwajowym spowodowały konieczność nowych rozwiązań w zakresie chłodnic. Innowacyjnym pomysłem takiego rozwiązania autorstwa firmy ABB [4], jest między innymi umieszczenie chłodnicy silników trakcyjnych i falowników w jednej oddzielnej skrzyni ( kontenerze). Skrzynia ta jest umieszczona na dachu tramwaju $\mathrm{z}$ obniżoną podłogą. Przykład takiego rozwiązania jest podany na rys. 3 .

Rys.3. Chłodnica asynchronicznych silników trakcyjnych wraz z falownikiem umieszczone w jednej obudowie skrzynkowej wg [4]




Gatunki stali wytypowane do budowy pudeł tramwajów niskopodłogowych wg $[5]^{1)}$ Tabela 5

\begin{tabular}{|c|c|c|c|c|c|c|}
\hline L.p. & $\begin{array}{c}\text { Gatunek } \\
\text { stali }\end{array}$ & $\begin{array}{c}\text { Wytrzymałość na } \\
\text { rozciąganie } \mathbf{R}_{\mathbf{m}} \\
{\left[\mathbf{N} / \mathbf{m m}^{2}\right]}\end{array}$ & $\begin{array}{c}\text { Granica } \\
\text { plastyczności } \\
\mathbf{R}_{\mathbf{p} \mathbf{0 . 2}}\left[\mathbf{[ N / \mathbf { m m } ^ { 2 } ]}\right.\end{array}$ & $\begin{array}{c}\text { Możliwość } \\
\text { formowania } \\
\text { (np. gięcie) }\end{array}$ & $\begin{array}{c}\text { Dostawa } \\
\text { profilów }\end{array}$ & Koszty \\
\hline 1. & St 52-3 & $490 \div 630$ & 335 & dobra & tak & $100 \%$ \\
\hline 2. & COR-TEN B & $490 \div 630$ & 355 & dobra & utrudniona & $112 \%$ \\
\hline 3. & 1.4003 & $450 \div 600$ & $320 \div 370$ & $\begin{array}{c}\text { dobra z ogranicze- } \\
\text { niami }\end{array}$ & utrudniona & $264 \%$ \\
\hline 4. & 1.4589 & $550 \div 700$ & $420 \div 450$ & $\begin{array}{c}\text { dobra z ogranicze- } \\
\text { niami }\end{array}$ & tak & $340 \%$ \\
\hline
\end{tabular}

Obecnie producent ABB Schweiz w Turgi (Szwajcaria) poddaje próbom wszystkie urządzenia i sprawuje nadzór konstrukcyjny przy uruchomieniu pierwszego pojazdu, nie jest jednak dostawcą wyposażenia elektrycznego w klasycznym sensie jak ma to miejsce $\mathrm{w}$ przypadku uznanych producentów jak Alstom, Bombardier Transportation w Brush, Siemens Transportation Systems, Elin BBG lub Vossloh Kiepe.

\section{Konstrukcja nadwozia tramwaju}

Nadwozie tramwaju we współczesnych pojazdach musi spełniać wiele kryteriów, które w głównej mierze sprowadzają się do utrzymania możliwe niskiej masy własnej. Stwierdzono, że przy konstrukcjach stalowych pudła wagonu w stanie surowym dla pojazdów tramwajowych o porównywalnej budowie wskaźnik jednostkowej masy własnej (przeliczony na powierzchnię użytkową pojazdu) wynosi ok. 100 $\mathrm{kg} / \mathrm{m}^{2}$ oraz że jego masa własna jest większa niż masa wyposażenia, przy czym jednostkowa masa własna wyposażenia nadwozia wynosi ok. $79 \div 118 \mathrm{~kg} / \mathrm{m}^{2}$. Cel rozwojowy powinien być tak sformułowany, aby pudło wraz z wyposażeniem posiadało masę własną nie większą niż $8400 \mathrm{~kg}$. Wyposażenie pudła pojazdu nie powinno wymagać dużego nakładu pracy, posiadać małą masę własną nie przekraczającą $4200 \mathrm{~kg}$ ( ok.86 $\mathrm{kg} / \mathrm{m}^{2}$ ) i innowacyjne rozwiązania. W przypadku utrzymania proporcji masowych pudła pojazdu w stosunku do jego wyposażenia 50:50, masa pudła nie powinna być większa aniżeli $4200 \mathrm{~kg}$. W wyniku prac studialnych pożądaną masę pudła pojazdu można osiagnąć przy zastosowaniu wysokowytrzymałych stali nierdzewnych.

Materiały, które mogą być użyte do budowy pudła pojazdu tramwajowego sa dobierane wg kryterium minimalnej masy własnej i muszą być użyte w postaci cienkościennych profili (niem. „dünnwandige Profile") o bardzo dużej odporności na korozję. Przykłady wysokowytrzymałych stali, które mogą być brane pod uwage do budowy pudła pojazdu tramwajowego przedstawiono w tabeli 5 .

Analizując materiały przedstawione w tabeli 5 projektanci taboru tramwajowego zdecydowali się na zastosowanie stali 1.4003 , przyjmując następujące kryteria:

> większa odporność na korozję niż dla stali COR-TEN B
> większa wytrzymałość zmęczeniową niż dla stali 1.4589

$>$ podobne wartości wytrzymałości jak dla stali St 52-3

$>$ możliwość, aby uzyskać doświadczenia w ramach rozwoju konstrukcji prototypowej

$>$ nieznaczne zwiększenie kosztów całkowitych w stosunku do stali COR-TEN B.

Kolejny etap poszukiwania nowych materiałów polega między innymi na możliwości zastosowania materiałów o mniejszej gęstości ( masie właściwej) niż stale, $z$ przedstawieniem wytrzymałości na rozciaganie $R_{m}$ oraz ze wskaźnikiem długości rozrywania $I_{R}$ ( niem.,Reisslänge”), który definiuje się jako długość pręta, który rozrywa się pod wpływem masy własnej.

Wskaźnik rozrywania dla danego materiału określa się ze wzoru:

$$
I_{R}=\frac{R_{m}}{m}=\frac{R_{m}}{V \cdot \rho}
$$

gdzie:

$$
\begin{aligned}
& \text { V-objętość pręta } \\
& \rho \text { - masa właściwa. }
\end{aligned}
$$

Odpowiednie zestawienie dla różnych materiałów, które rozpatrywano pod kątem zastosowania w konstrukcjach lekkich pudeł tramwajowych przedstawiono na rys.4.

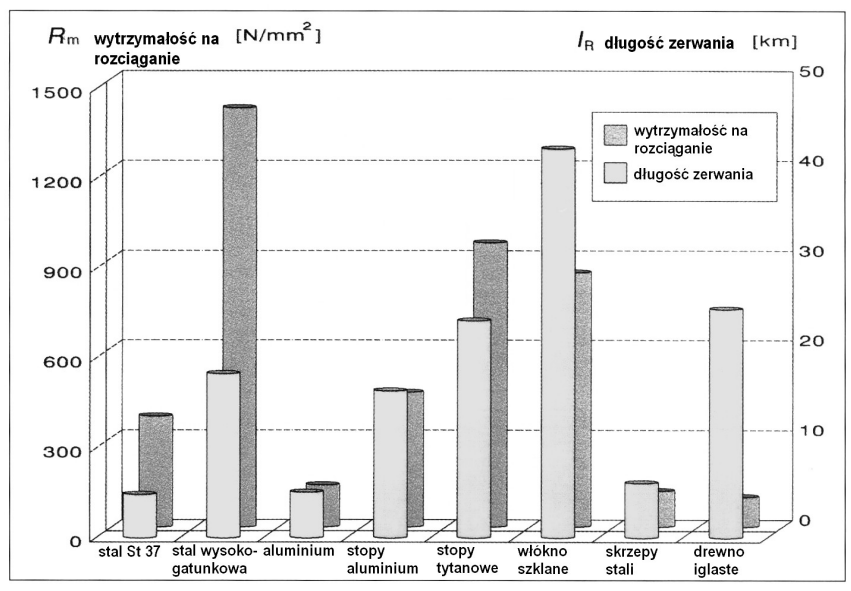

Rys.4. Porównanie wybranych parametrów wytrzymałościowych $R_{m}{ }_{i} I_{R}$ dla analizowanych materiałów pod kątem przydatności dla ultralekkich konstrukcji wg [1] 
Jak wynika z rys.4, stopy tytanowe oraz tworzywa sztuczne wzmocnione włóknami szklanymi mogą być brane pod uwagę ze względu na parametry wytrzymałościowe, natomiast nie są konkurencyjne z punktu widzenia możliwości obróbki mechanicznej oraz ceny. W przypadku stopów aluminium i stali o wysokich parametrach wytrzymałościowych porównanie daje zdecydowanie inne rezultaty. Jeśli dodatkowo porównać parametr sztywności wyrażony iloczynem E.J (gdzie: E- moduł Younga, a J- powierzchniowy moment bezwładności), to wówczas okazuje się, że aluminium posiada o $2 / 3$ mniejszy moduł Younga. Aby osiągnąć analogiczną sztywność należy liczyć się z tym, że należy zwiększyć przekroje poprzeczne powierzchni. Do tego dochodzą koszty inwestycji związane $\mathrm{z}$ uruchomieniem linii produkcyjnej stopów aluminiowych, względnie mała możliwość przystosowania technologii, problemy z drganiami i akustyczne oraz podatność na powstawanie pęknięć spawalniczych. Praktyka wykonawcza pudeł pojazdów szynowych, wyprodukowanych całkowicie ze stali lub z aluminium dowodzi, że procesowi wytwarzania towarzyszą bardzo długie spoiny, wynikające z tego skurcze cieplne i związana $z$ tym obróbka cieplna oraz mechaniczna bądąca poważnym problemem technologicznym i konstrukcyjnym. Dlatego rozpatrzono możliwość zastosowania modułowej konstrukcji hybrydowej (niem.,, modulare Hybridenbauweise”)[15]. Główną jej ideą jest zastosowanie kombinacji różnych materiałów, przy której dominują półprodukty stalowe z możliwością wykonania niektórych podzespołów z aluminium albo tworzyw sztucznych. Pudło pojazdu o klasycznej budowie nie występuje więcej w nowoczesnych konstrukcjach pojazdów tramwajowych. Modułowość definiuje się w kompatybilnym wyborze elementów, podzespołów i metod wytwarzania, jak również techniki montażowej i połączeniowej. Przykładem innowacyjnego połączenia jest zastosowania kombinacji profilów wielkogabarytowych oraz konstrukcji typu dzielonego. Przykładem takich konstrukcji jest opatentowany system śrubowy typu „ALUSUISSE” (rys.5)[5].

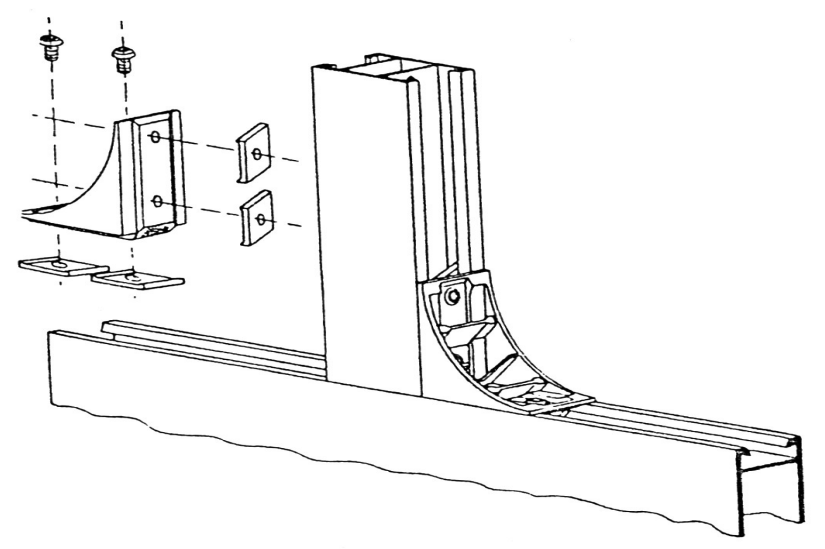

Rys.5. Przykład łączenia konstrukcji wielkogabarytowych oraz systemu śrubowego typu „ALUSUISSE” wg [5]
Kolejny przykład zastosowania oryginalnej techniki łączeniowej jest podany na rys. 6 i 7 .

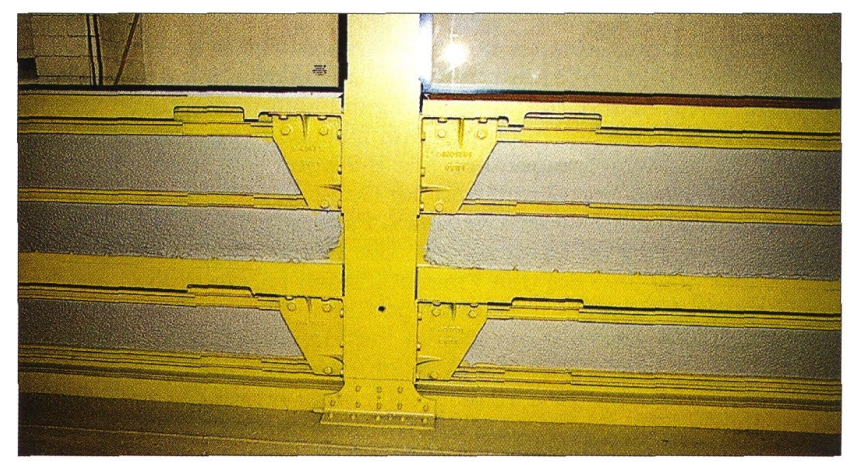

Rys.6. Mocowanie ścian bocznych pudła tramwajowego za pomocą węzłówek śrubowych łączących pionowe i wzdłużne profile głębokotłoczne ( niem.,, Strangpressprofile") oraz zastosowanie nitów, łączących profile wzdłużne i z podłogą pojazdu tramwajowego „CitySprinter” produkcji Siemens Transportation Systems wg [3]

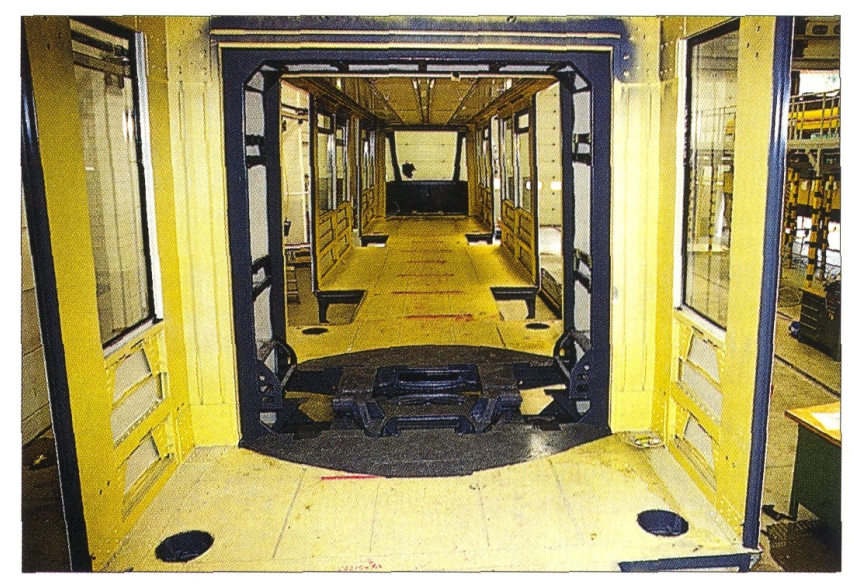

Rys.7. Przykład zastosowania połączeń nitowanych na profilach głębokotłocznych $\mathrm{z}$ kombinacją węzłówek śrubowych łączących z podłogą pojazdu tramwajowego „CitySprinter” produkcji Siemens Transportation Systems wg [3]

\section{Pojazdy tramwajowe bez sieci jezdnej}

Wysokość użytkowa pudła jest niewątpliwie obok jej szerokości istotnym parametrem pojazdu. Ogranicza go na pewno górny zarys odniesienia skrajni kinematycznej oraz budowli. Elementem, który ogranicza od góry zastosowanie większej wysokości pojazdu jest niewątpliwie układ odbierak prądu-sieć jezdna. W związku z powyższym kontynuowane są prace nad pojazdami tramwajowymi nowej generacji bez sieci jezdnej ( niem.,, Strassenbahnen ohne Oberleitung” lub „fahrdrahtlose Strassenbahnen”) [7]. Krajami najbardziej zaawansowanymi w pracach nad nowymi rozwiązaniami są Francja i Niemcy. Francuski system typu APS ( franc. ,alimentation ?lectrique par le sol") polega na zasilaniu pojazdu systemu tramwajowego przez przewód umieszczony u dołu. Został on opracowany przez firmę Alstom oraz zamówiony dla pojazdów eksploatowanych w Bordeaux, Angers, Orleans i Reims. System APS okazał się bardzo awaryjny z uwagi na wrażliwość przewodu zasilającego na 
czynniki klimatyczne jak np. śnieg, lód i silne deszcze oraz oddziaływań zanieczyszczeń. Koszty inwestycyjne związane z systemem APS są czterokrotnie większe niż dla klasycznego przewodu jezdnego, natomiast koszty utrzymania prawie 50 razy większe. Niemiecki system stosuje zespół zasilający o budowie modułowej jako kontenera $\mathrm{z}$ umieszczonymi kondensatorami wysokiej mocy (niem. „Hochleistungskondensatoren”) zamontowany na dachu pojazdu tramwajowego (ang.,, Supercap with MITRAC Energy Saver"). Zespół ten został zaprojektowany i wyprodukowany przez Bombardier Transportation, natomiast tramwaje $\mathrm{z}$ takim rozwiązaniem technicznym określa się jako pojazdy typu „Supercap” ( niem. „Supercapfahrzeugen”). Ich rezultatem może być nie tylko oszczędność energii trakcyjnej o ok. 30\% przy bezawaryjnej eksploatacji, ale również zwiększenie miejsca $\mathrm{w}$ górnych partiach pojazdu, co potwierdziły pierwsze czteroletnie próby przeprowadzone przez przewoźnika Rhein-NeckarVerkehr GmbH (RNV) w Mannheim od lata 2003 roku. Jak wynika $\mathrm{z}$ pierwszych przeprowadzonych prób w Heidelbergu ( posiada 8 pojazdów tego typu) oraz w Monachium ( posiada jeden pojazd tego typu) z pojazdami prototypowymi całkowita rezygnacja $\mathrm{Z}$ sieci jezdnej z punktu widzenia obecnego stanu techniki nie jest jeszcze możliwa, biorąc pod uwagę chociażby względy kosztowe lub niezawodnościowe. Na razie za tym rozwiązaniem przemawiają względy oszczędności energii. Zużycie energii w nowoczesnym pojeździe tramwajowym jest 5-cio krotnie większe aniżeli dla tramwajów z lat 50-tych, zakładając tę samą wydajność przewozową we wskaźniku będącym iloczynem ilości pasażerów i kilometrów. Przewód jezdny przy dzisiejszych rozwiązaniach technicznych może posiadać mniejszy przekrój, ale przede wszystkim odciążone są podstacje zasilające. Zapotrzebowanie na prąd szczytowy spada o 50\%. Inwestycje na obecnym poziomie polegające na dodatkowym wyposażeniu pojazdu w Heidelbergu wynoszą 270000 EUR na pojazd tramwajowy i gwarantują zwrot kosztów $\mathrm{z}$ tytułu mniejszego zapotrzebowania na energię po 15 latach z tytułu oszczędności energii w wysokości 295000 EUR. W przypadku zastosowania hamowania odzyskowego, czyli magazynowania energii hamowania przez zasobniki (niem.,,Bremsenergiespeichern”) zwrotu kosztów inwestycyjnych z tytułu mniejszych oszczędności energetycznych można oczekiwać po 10 latach.

\section{Zakończenie}

$\mathrm{Na}$ podstawie przedstawionych przykładów tendencji rozwojowych pojazdów tramwajowych można wyciagnąć wniosek, że sprowadzają się one do:

$>$ budowy lekkich konstrukcji poprzez określenie maksymalnej masy

$>$ zastosowanie nowych materiałów konstrukcyjnych [2 i 16$]$
$>$ modułowej budowy pojazdu $[3,4,5,14$ i 15$]$

$>$ bardzo dobrej ochrony przeciwkorozyjnej

$>$ zastosowania nowych koncepcji wykonawczych

$>100 \%$ udziału niskiej podłogi

$>$ optymalnego wykorzystania przestrzeni, zwłaszcza $\mathrm{z}$ uwzględnieniem szerokości pojazdów, wynoszących 2,3 m do 2,65 m

$>$ prostych napraw uszkodzeń powypadkowych, możliwie bez zastosowania specjalnych technologii wykonawczych jak np. spawanie [15].

Poszukiwanie optymalnego zarysu pojazdu tramwajowego w aspekcie zarysu skrajni kinematycznej oraz skrajni budowli jest powiązane z zapewnieniem jak najwyższego komfortu jazdy pasażerom przez który rozumie się bardzo dobre warunki przy wsiadaniu i wysiadaniu z pojazdu, dużą ilość miejsc siedzących, dużą szerokość korytarzy przejściowych pomiędzy miejscami siedzącymi, maksymalną ilość poręczy i uchwytów, możliwość korzystania z pojazdu tramwajowego przez osoby niepelnosprawne, osoby $z$ bagażem oraz z wózkami dziecięcymi. Do tego dochodzi konieczność zapewnienia najwyższego bezpieczeństwa dla podróżnych, czego przykładem może być możliwość obserwacji przez motorniczego pasażerów i pojazdu przez system kamer video, umieszczonych na zewnątrz pojazdu. Nowoczesne pojazdy tramwajowe posiadają obniżoną podłogę, co $\mathrm{w}$ konsekwencji prowadzi do bardzo ograniczonej przestrzeni dla układu biegowego oraz prowadzi do konieczności lokalizacji urządzeń pomocniczych na dachu. Poszukiwanie optymalnej przestrzeni dla pojazdu tramwajowego służy spełnieniu poważnego wyzwania rynkowego, jakim jest wyprodukowanie nowoczesnego środka komunikacji miejskiej, konkurującego skutecznie $\mathrm{z}$ innymi środkami transportu miejskiego, jakimi są samochody osobowe, autobusy, trolejbusy i pojazdy kolejowe metra. Należy zwrócić uwagę, że poszukiwania większego dopuszczalnego zarysu pojazdu, pośrednio tylko zmniejsza kłopoty wykonawcze producentom armatury elektrycznej oraz mechanicznej. Producent wyrobu finalnego, który sam znajduje się wobec „presji wymagań rynkowych" coraz bardziej wywiera nacisk na wykonanie aparatury o coraz mniejszych wymiarach gabarytowych oraz o mniejszej masie. Istotnym ograniczeniem poszukiwania konstrukcji „ultralekkich” jest częstotliwość własna drgań giętnych pudła $\mathrm{w}$ stanie surowym oraz wraz $\mathrm{z}$ wyposażeniem, która nie powinna być mniejsza niż odpowiednio $7,5 \mathrm{~Hz}$ oraz $9 \div 10 \mathrm{~Hz}$ zgodnie z [5].

\section{Literatura}

[1] Altenburg K. Quo-vadis Waggonbau?- Einige aktuelle Konzepte und Richtungen der Bauweisenentwicklung im Waggonbau. ZEV+DET Glasers Annalen Nr. 123, 11/12, 1999. 
[2] Dillig G.: Aluminium-ein etablierter Werkstoff im Schienenfahrzeugbau. Stadtverkehr Nr. 5/2000.

[3] Hondius H.: Der CitySprinter-Nachfolger des Stadtbahn-B-Wagens. Stadtverkehr 9/1999.

[4] Hondius H.: Entwicklung der Niederflur-Strassenbahn -und Stadtbahnen. Stadtverkehr 1-2 12008 .

[5] Müller A.: Niederflur-Stadtbahnwagen. Eine neue Fahrzeuggeneration. Vorträge der ETG Fachtagung vom 13 bis 14 März 1990 Kassel. ETGFachbericht Nr.31.

[6] Neudorfer H.: Flüssigkeitsgekühlte DrehstromTraktionsmotoren. ZEV+DET. Glasers Annalen Nr124, 5/2001.

[7] Neumann T.: Strassenbahnen ohne Oberleitung. Stadtverkehr 3/2008.

[8] Sobaś M.: Skrajnia kinematyczna i budowli pojazdów tramwajowych. Pojazdy Szynowe nr 3/2007.

[9] Sobaś M.: Analiza przemieszczeń geometrycznych i kinematycznych krajowych pojazdów tramwajowych na torze prostym oraz na tuku o minimalnym promieniu. Pojazdy Szynowe nr 4/2007.

[10] Sobaś M.: Luzy bezpieczeństwa pomiędzy skrajnia kinematycznq $i$ skrajniq budowli dla pojazdów tramwajowych (1). Pojazdy Szynowe nr 1/2008.
[11] Sobaś M: Luzy bezpieczeństwa pomiędzy skrajniq kinematyczna i skrajniq budowli dla pojazdów tramwajowych (2). Pojazdy Szynowe nr 1/2008.

[12] Sobaś M.: Możliwości ksztaltowania optymalnego zarysu pojazdu tramwajowego. Pojazdy Szynowe nr 2/2008.

[13] Sobaś M.: Możliwości ksztaltowania optymalnego zarysu pojazdu tramwajowego w świetle aktualnie obowiqzujacych przepisów bezpieczeństwa jazdy, komfortu pasażerów i ergonomii pracy motorniczego. Pojazdy Szynowe nr 2/2008.

[14] Wimmer D.: Energieeinsparung durch neue Bordnetzumrichter. Elektrische Bahnen Nr. 104, 2006 Heft 7.

[15] Zehnder J.: Neuartige Struktur in AluminiumHybridenweise für Nahverkehrsfahrzeuge. ZEV+ DET Glasers Annalen Nr.121, 2/3 1999.

[16] Żmuda-Sroka M.M.: Materiały lekkie do budowy pojazdów szynowych. Technika Transportu Szynowego. 5/1999.

[17] Siemens Transportation Systems: Siemens liefert 21 Combino Strassenbahnen nach Bern. ZEVrail Glasers Annalen Nr.132, 3/2008. 